\title{
Konvergensi Konten Majalah Popular dalam Industri Digital Media Cetak
}

\author{
Citra Eka Putri ${ }^{1}$, Radja Erland Hamzah ${ }^{2}$ \\ ${ }^{1}$ Program Pascasarjana Ilmu Komunikasi Universitas Prof.Dr.Moestopo (Beragama) \\ Jl. Hang Lekir 1 No. 8 Jakarta Pusat - Indonesia \\ ${ }^{2}$ Fakultas Ilmu Komunikasi Universitas Prof.Dr.Moestopo (Beragama) \\ Jl. Hang Lekir 1 No. 8 Jakarta Pusat - Indonesia \\ Correspondent author: ekaputricitra8@gmail.com
}

\begin{abstract}
The development of communication technology rapidly growing, affecting the print of media industry. A number of print media in Indonesia began to close because it is not able to compete with other digital media, so that print media managers make various efforts to maintain its median existence by converging Media by preparing digital media based, one of them is Popular Magazine. The purpose of this study is to determine the efforts made by POPULAR in maintaining its life as an answer to the development of media information technology industry. The results of this study indicate that the model of media convergence by Popular magazine is a Content convergence, the model involving Social media in which in this model, popular magazines try to penetrate to all social media and multiplatform to be able to exist in Media industry.
\end{abstract}

Keywords: Existence, Convergence, Popular Magazine, Efforts

\begin{abstract}
Abstrak - Perkembangan tekonologi komunikasi saat ini yang bertumbuh pesat, berpengaruh pada industri media cetak. Sejumlah media cetak di Indonesia mulai tutup karena tidak mampu bersaing dengan media digital lainnya, sehingga pengelola media cetak melakukan berbagai upaya untuk mempertahankan eksistensi medianya dengan melakukan convergensi, dan menyiapkan media berbasis digital, salah satunya Majalah pria dewasa "Popular". Tujuan penelitian ini adalah untuk mengetahui upaya yang dilakukan oleh majalah Popular dalam mempertahankan hidupnya sebagai jawaban atas perkembangan tekhnologi industri informasi media. Hasil penelitian ini menunjukkan, majalah Popular menempuh model konvergensi Content dan tampil di berbagai platform sosial dengan satu tujuan: mempertahakan eksistensi keberadaan majalah Populer dalam industri Media Massa.
\end{abstract}

Kata Kunci: Eksistensi, Konvergensi media, Majalah Popular, Upaya

Copyright @ 2018 Ikatan Sarjana Komunikasi Indonesia. All rights reserved

\section{PENDAHULUAN}

Disadari atau tidak Perkembangan teknologi komunikasi mengalami perkembangan pesat dalam dua dasa warsa terakhir. Perkembangan teknologi yang demikian pesat itu juga merambah industri media. Media digital menjadi media yang sedang populer dalam beberapa tahun terakhir. Beberapa kalangan kemudian meramalkan media cetak bakal tergusur oleh teknologi media yang berbasis digital akibat kemunculan teknologi digital media cetak. Bahkan, media cetak diprediksi akan mati dalam 20 tahun ke depan. Dengan munculnya internet, surat kabar kertas akan digantikan berita digital yang ditandai dengan banyaknya pembaca koran beralih ke koran digital yang tersaji di komputer tablet atau smartphone.

Di Amerika Serikat, kematian media cetak mulai terjadi karena tidak mampu melawan perubahan teknologi informasi. Newsweek, majalah paling populer yang berumur 85 tahun berhenti cetak pada akhir 2012 dan berganti wajah menjadi media digital per Januari 2013. Sebelumnya pada 2009, The Rocky Mountain News mengakhiri edisi cetak dan meninggalkan 117.600 pembacanya. 
The Seattle Post Intelligence yang sudah berusia 146 tahun juga bernasib sama. Revolusi teknologi informasi, juga mengganggu "kesehatan" koran besar di AS. The Washington Post yang terpaksa harus memangkas sejumlah biaya, menutup sejumlah biro dan mengurangi karyawannya. Hal yang sama juga terjadi di Indonesia dengan tutupnya sejumlah media massa cetak (Kompas.com, 14 Oktober 2012, Nainggolan, 2017, Ritonga, 2017).

Pada 2015, Sinar Harapan, Harian Bola dan Jakarta Globe tutup, dan terakhir tabloid Bola. Mereka tidak mampu bertahan di industri media cetak karena gempuran media online. Nielsen Indonesia menyatakan, saat ini pembaca media digital sudah lebih banyak ketimbang media cetak. Jumlah pembeli koran terus merosot dalam empat tahun terakhir karena masyarakat beranggapan bahwa informasi seharusnya bisa didapat secara gratis. Oleh karena itu, banyak upaya dilakukan oleh media cetak untuk mempertahankan hidupnya, termasuk berupaya menampilkan sudut pemberitaan yang langka, dan menarik, termasuk memberi perhatian lebih pada perempuan dari sudut pandang feminisme (Ritonga, dkk, 2017).

Survei Nielsen Consumer \& Media View hingga triwulan ketiga 2017 menyatakan, kebiasaan membaca orang Indonesia telah mengalami pergeseran. Pada 2017, tingkat pembelian koran secara personal hanya sebesar 20\%, menurun dibandingkan 2013 yang mencapai $28 \%$. Anggapan bahwa media harus gratis mengerek tingkat penetrasi media digital hingga $11 \%$ dengan jumlah pembaca 6 juta orang pada tahun ini. Jauh lebih banyak dibanding pembaca media cetak sebanyak 4,5 juta orang. Padahal, jumlah pembaca media cetak pada 2013 bisa mencapai 9,5 juta orang. Sementara, jumlah pembaca media cetak sekaligus digital hanya 1,1 juta orang. Selain itu, media cetak hanya menjadi pilihan kelima masyarakat untuk mendapatkan informasi dengan penetrasi sebesar $8 \%$. Sementara, urutan pertama ditempati televisi dengan $96 \%$, kemudian papan iklan di jalanan 52\%, penggunaan internet sebesar $43 \%$, dan radio sebanyak $37 \%$.

Untuk penetrasi media cetak, masyarakat memilih koran dengan porsi $83 \%$, tabloid $17 \%$, dan majalah 15\%. Survei Nielsen yang dilakukan di 11 kota dengan mewawancarai 17 ribu responden dan mencapai populasi sebanyak 54 juta orang menyatakan, masyarakat yang membaca media cetak pun didominasi oleh orang-orang berusia 20-49 tahun dengan porsi sebanyak $73 \%$. Hanya 10\% anak muda berusia 10-19 tahun yang mengakses media cetak sebagai sumber informasinya. Sebaliknya, sebanyak 17\% anak muda berusia 10-19 memperoleh informasi lewat internet. Untuk pembaca berusia 20-49 tahun jumlahnya sebesar 80\% (katadata.co.id, 7 Desember 2017).

Namun demikian, Presiden WAN-IFRA, Jacob Mathew dalam pembukaan Publish Asia 2012 di Bali mengatakan koran dan media cetak lainnya, masih menjadi andalan bagi pelaku usaha media Asia. Keberadaan media cetak masih sangat dibutuhkan di kawasan Asia. Tiga perempat dari 100 surat kabar terbesar di dunia terbit di Asia. Surat kabar menjadi sumber informasi primer. Meski demikian, Jacob mengingatkan bahwa tantangan yang dihadapi surat kabar di negara Barat juga akan dialami surat kabar di Asia, terutama pesatnya perkembangan media online. Beberapa negara Asia saat ini juga menjadi pusat pertumbuhan era digital dan teknologi (Kompas.com, 12 April 2012).

Di Indonesia, ada beberapa media nasional yang telah menerapkan konsep konvergensi antara lain Grup Kompas Gramedia, Grup Tempo, Grup Jawa Pos, dan lain-lain. Di sisi lain, beberapa majalah sudah tidak terbit seperti majalah pria dewasa MAXIM, FHM dan Playboy Indonesia. Salah satu majalah pria dewasa yang masih eksis adalah majalah Popular. Majalah dengan genre majalah pria dewasa itu terbit setiap minggu dan untuk itu mereka berusaha menyesuaikan dengan perkembangan teknologi. 
Ancaman kematian media cetak sebagaimana disampaikan para pakar media sebagai efek atas derasnya media online diantisipasi oleh para pengelola majalah Popular dengan melakukan konvergensi media. Pada 2012, Popular membangun web resmi www.popular-world.com, selanjutnya merambah ke media sosial pada awal tahun 2014: hadir di instagram, facebook dan youtube. Keberadaan Popular di beberapa platform media sosial tersebut, merupakan strategi untuk mempertahankan eksistensi mereka agar tetap eksis dalam persaingan industri media saat ini.

Dengan mengamati persoalan yang dihadapi, khususnya pers cetak berbentuk majalah, maka penelitian ini berupaya mencari jawab atas persoalan "bagaimana model konvergensi yang dilakukan majalah Popular dalam mempertahankan eksistensi dirinya di era digital saat ini”. Penelitian ini merupakan penelitian deskriptif kualitatif dengan memaparkan deskripsi, gambaran atau lukisan secara sistematis, faktual dan akurat mengenai fakta-fakta, sifat-sifat serta hubungan antarfenomena yang diselidiki. Teknik pengambilan informan dilakukan secara purposive sampling (pengambilan informan berdasarkan tujuan), sedangkan teknik pengumpulan data dilakukan dengan wawancara, dokumentasi dan studi pustaka. Data penelitian yang diperoleh kemudian dianalisis secara kualitatif.

\section{KERANGKA TEORI}

Pers cetak diyakini sudah memasuki fase senjakala, dengan anak-anak muda tidak lagi mengakses informasi dari media massa cetak. Namun begitu, media cetak masih ada dan bertahan. Salah satu tantangan yang dihadapi pers cetak adalah menghadirkan berita baru. Sebab, semua materi yang didapat dari hasil liputan kemarin sudah beredar di dunia maya. Wartawan media online sudah merampungkan pekerjaannya dengan baik, namun, wartawan media cetak tidak bisa dikalahkan begitu saja.

Wartawan media cetak tidak perlu terburu-buru. Mereka punya waktu hingga malam hari untuk bisa meramu dan menjalankan upaya untuk menjadikan tulisannya menjadi eksklusif dan baru. Selesai bertemu narasumber, wartawan media cetak bisa melakukan riset latar belakang masalah lebih dalam. Kalau perlu, mereka menghubungi narasumber lain dan mencari data baru untuk melengkapi cerita. Narasumber inilah yang bisa memberikan perspektif baru pada artikel yang terbit keesokan hari. Membuat berita yang lebih dalam akan menguras pikiran wartawan media cetak, sehingga mereka tidak akan membuat berita terlalu banyak. Wartawan koran hanya diberi beban satu atau dua tulisan dalam sehari.

Media cetak membebaskan khayalak dari tirani prime time. Koran atau majalah memberikan infomasi yang dapat dibaca kapan saja, sesuka khayalak dan bukan pada waktu yang ditentukan, seperti halnya di radio dan televisi. Media cetak tergolong praktis, cepat, dengan harga terjangkau. Daya jangkau dan edar media cetak dapat sampai pelosok. Kedalaman liputan media cetak bersifat informatif dengan narasi panjang, bersifat massal, fleksibel, dan dapat dibaca dimana saja dan kapan saja.

Berikut beberapa karateristik media cetak majalah yaitu: (1) Publisitas, penyebaran pada publik atau khalayak, (2) Cover sebagai daya tarik, (3) Cover dapat menjadi ciri suatu majalah yang membedakan dengan yang lain, (4) Periodesitas, menunjuk pada keteraturan terbit, (5) Universal, menunjuk pada kesemestaan isinya, aneka ragam, meliputi seluruh aspek kehidupan manusia, (6) Aktualitas, menunjuk pada kekinian atau terbaru dan masih hangat, (7) Terdokumentasikan, dapat di simpan untuk menjadi rujukan sejarah, (8) Penyajian lebih dalam, karena majalah pada umumnya adalah mingguan, dwimingguan, bulanan sehingga memiliki waktu cukup lama untuk memahami dan mempelajari peristiwa, (9) Nilai aktualitas lebih, membaca majalah tidak pernah dituntaskan 
sekaligus akan tetapi aktual hingga terbit yang baru, (10) Gambar foto lebih banyak, majalah dapat menampilkan foto lengkap, ukuran besar dan kualitas cetak yang lebih baik.

Majalah pada umumnya adalah sebuah media publikasi atau terbitan secara berkala yang memuat artikel-artikel dari berbagai penulis. Selain memuat artikel, majalah juga merupakan publikasi yang berisi cerita pendek, gambar, review, ilustrasi atau fitur lainnya yang mewarnai isi dari majalah. Oleh karena itu, majalah dijadikan salah satu pusat informasi bacaan yang sering dijadikan bahan rujukan oleh para pembaca dalam mencari sesuatu hal yang diinginkannya.

Menurut beberapa pakar media, majalah adalah alat komunikasi yang bersifat umum dan terbit secara teratur, yang berfungsi sebagai penyebar luasan informasi dan sarana perjuangan untuk mencapai cita-cita pembangunan. Kurniawan Junaedhi menyatakan pengertian majalah adalah sebuah penerbitan berkala (bukan harian) yang terbit secara teratur dan sifat isinya tak menampilkan pemberitaan atau sari berita, melainkan berupa artikel, atau yang bersifat pembahasan yang menyeluruh dan mendalam. Media yang satu ini menjadi primadona banyak orang selain koran atau surat kabar.

Aneka macam majalah dapat dengan mudah dijumpai, mulai dari majalah wisata, majalah politik, majalah bisnis, majalah salon kecantikan, majalah gaya hidup bahkan salah satunya adalah majalah pria dewasa. Banyaknya jenis-jenis majalah tersebut memperlihatkan keterbukaan informasi yang semakin lebar. Dengan jumlah eksemplar dan pembaca yang banyak, majalah menjadi media yang menarik bagi para pengiklan.

Waktu terbit majalah bisa bervariasi, bisa seminggu sekali, dua minggu sekali, satu bulan sekali bahkan ada yang terbit tiga bulan sekali. Dengan waktu terbit yang relatif lebih lama dibandingkan koran, majalah mempunyai waktu baca yang lebih lama (long life span). Informasi yang ditampilkan di majalah pun dikemas secara lebih menarik dan mendalam.

Tampilan majalah dapat dikatakan lebih eksklusif, satu hal yang membuat majalah terlihat menarik yaitu tampilannya. Dengan jenis kertas yang lebih bagus, kualitas gambar yang tampil di kertas terlihat lebih jelas. Gambar-gambar dan teks yang ditampilkan di halaman majalah umumnya semuanya berwarna (fullcolour). Untuk menarik minat pembaca, majalah menampilkan sampul depan atau cover yang selalu berganti dari satu edisi ke edisi lainnya. Salah satu caranya yaitu memperlihatkan model yang cantik atau ganteng di bagian sampul majalah. Model sampul majalah itu merupakan model, artis sinetron atau bintang iklan terkenal yang banyak jadi idola banyak orang. Hal itu biasanya banyak kita lihat di majalah-majalah gaya hidup atau fashion.

Tipe atau kategori suatu majalah ditentukan oleh sasaran pembacanya yang dituju. Artinya, sejak awal redaksi sudah menentukan siapa yang akan menjadi pembacanya, apakah anak-anak, remaja, wanita dewasa, pria dewasa, atau pembaca umum artinya dari anak-anak hingga orang dewasa. Bisa juga sasaran pembaca yang dituju dari kalangan profesi tertentu, seperti pelaku bisnis atau pembaca dengan hobi tertentu seperti bertani, berternak dan memasak. pada penelitian ini peneliti mengambil contoh majalah pria dewasa, dimana majalah ini berisi semua hal yang disukai oleh pria dewasa, dari mulai hobi sampai gambar-gambar wanita cantik ada didalamnya.

Konvergensi media merupakan salah satu perkembangan media massa yang melibatkan banyak faktor teknologi di dalamnya. Kehadiran internet mendorong media massa menerapkan konsep konvergensi media seperti media online, e-paper, e-books, radio streaming, media sosial, yang digabungkan dengan media lainnya. Terry Flew dalam An Introduction to New Media (2002) menyatakan konvergensi media merupakan hasil dari irisan tiga unsur new media yaitu jaringan komunikasi, teknologi informasi, dan konten media. Konvergensi media mengusung pada konsep 
penyatuan berbagai layanan informasi dalam satu piranti informasi membuat satu gebrakan digitalisasi yang tidak bisa dibendung lagi arus informasinya.

Konvergensi menyebabkan perubahan radikal dalam penanganan, penyediaan, distribusi dan pemrosesan seluruh bentuk informasi baik visual, audio, data dan sebagainya (Preston, 2001). Menurut Fiddler (2003: 29) terjadinya konvergensi media juga didukung oleh berbagai hal seperti kekuatan-kekuatan ekonomi, politik, dan sosial yang memainkan peran besar dalam penciptaaan teknologi-teknologi baru; berbagai penemuan dan inovasi tidak diadopsi secara luas lantaran keterbatasan teknologi itu sendiri; dan adanya kesempatan dan alasan ekonomi, sosial, dan politik yang mendorong perkembangan teknologi baru.

Michael O Wirth (2006: 447) mengatakan konvergensi media fokus pada konvergensi teknologi, konvergensi fungsi, konvergensi kompetitif dan konvergensi struktur industri. Konvergensi media terjadi karena didorong oleh kemajuan teknologi, khususnya media online (cybermedia), fungsi media dan kompetisi media. Konvergensi media adalah beberapa produk media yang akan lebih baik diproduksi bersama daripada terpisah agar lebih efisien. Karena fungsi media adalah sama namun masing-masing mempunyai karakter yang berbeda. Dengan konvergensi maka akan tercapai struktur industri yang lebih kuat dan target audiens yang lebih luas. Strategi manajemen media yang menghubungan dengan lingkungan eksternal telah mulai menghubungkan dengan strategi konvergensi (Albarran, 2006).

Konvergensi industri media dan teknologi digital mengarah pada bentuk-bentuk yang dikenal sebagai komunikasi multimedia. Multimedia atau dikenal juga sebagai media campuran, pada umumnya didefinisikan sebagai medium yang mengintegrasikan dua bentuk komunikasi atau lebih (Fiddler, 2003:39). Fiddler (2003) menyatakan kehadiran konvergensi media sebagai salah satu bentuk mediamorfosis yaitu suatu transformasi media komunikasi yang biasanya ditimbulkan akibat hubungan timbal balik yang rumit antara berbagai kebutuhan yang dirasakan, tekanan persaingan dan politik, serta berbagai inovasi sosial dan teknologi.

Adopsi teknologi digital oleh perusahaan media massa dalam melahirkan konvergensi media didukung oleh faktor tekanan dalam bisnis media massa. Kini para perusahaan media massa berlomba-lomba menganut konvergensi (Ritonga, 2007). Jenkins (2006:10) telah menggunakan istilah konvergensi untuk menggambarkan kekuatan perubahan dalam industri media.

Komunikasi massa (pers, radio, televisi), perangkat fisik tunggal seperti kabel dan gelombang udara, yang pada masa lalu dalam bentuk terpisah, kini dapat diakomodasi oleh satu medium seperti penyiaran, pers, dan komunikasi lewat telepon.

A process called "a covergence modes" is blurring the media, even between point-to-point communications, such as the post, telephone and telegraph, and mass communications, such as the press, radio, and television. A single physical means-be it wires, cables or airwavesmay carry services that in the past were provided in separate ways. Conversely, a service that in the past was provided by any one medium-be it broadcasting, the press, or telephonycan now be provided in several different physical ways. So the one-to-one relationship that used to exist between a medium and its use is eroding (Jenkins, 2006:10).

Transformasi media cetak ke arah konvergensi dapat mengadopsi jenis konvergensi yang dikemukakan oleh Grant (2009:33). Konvergensi jurnalistik mensyaratkan perubahan cara berpikir media tentang berita dan peliputannya. Bagaimana media memproduksi berita dan bagaimana media menyampaikan berita kepada khalayaknya. Namun, praktik konvergensi saat ini masih sebatas pada cara menyampaikan berita melalui platform yang berbeda yaitu media cetak, 
penyiaran, dan online. Dalam konvergensi jurnalistik dikenal adanya tiga model menurut August E Grant dalam bukunya Understanding Media Convergence: The state of the Field (2009), yaitu konvergensi newsroom, konvergensi newsgathering, dan konvergensi konten.

Konvergensi newsroom, dalam konvergensi ini jurnalis yang berbeda platform, misalnya dari surat kabar, online, dan televisi menyatukan dirinya dalam satu ruang produksi berita. Mereka mengerjakan tugas sesuai dengan platform medianya. Konvergensi newsgathering, dalam menjalankan model ini, seorang jurnalis dituntut untuk mampu mencapai tingkatan multitasking. Dengan melalui pelatihan atau training khusus, seorang jurnalis dituntut untuk dapat melakukan pekerjaan yang dilakukan oleh media dengan platform lain dalam satu grup. Misalnya, seorang wartawan cetak harus mampu membuat berita untuk cetak, online, dan sekaligus untuk televisi. Selain itu juga dituntut untuk mengambil foto atau video (Ritonga, 2007).

Konvergensi content, berita akhirnya disuguhkan dalam bentuk multimedia, yang merupakan kombinasi antara teks, gambar, audio, video, blog, podcasts, atau slide show. Pilihannya terus berkembang. Saat ini, konvergensi isi masih sangat muda atau baru dimulai. Namun, kita dapat mengintip masa depan melalui website yang inovatif. Bayangkan beberapa tahun ke depan medium hybrid baru mengkombinasikan antara audio dan video tv, sifat responsif dan sumber dari website, kemudahan dibawa dan kualitas cetak dari koran. Editor dan reporter akan menjadi content producer yang dilatih untuk memilih cerita mana yang paling efektif, teknik yang paling menghibur dari menu biasa hingga pilihan multimedia.

Teknologi informasi dan komunikasi yang semakin pesat pada abad ke-20 membuat wajah media massa berubah total. Jika semula beberapa pemilik media hanya memiliki satu platform, di era sekarang ini pemilik media bisa memiliki beberapa platform. Jika pemilik media semula memiliki platform cetak, kini pada awal tahun 2000 mulai dikembangkan ke platform lain seperti cetak dan online, cetak dan radio, cetak dan televisi atau malah cetak, online dan televisi.

Komunikasi yang sudah dikonvergensikan menyediakan berbagai macam alat untuk penyampaian berita, dan memungkinkan konsumen untuk memilih tingkat interaktivitasnya, seraya mereka bisa mengarahkan sendiri penyampaian kontennya. Konvergensi media memungkinkan audience (khalayak) media massa untuk berinteraksi dengan media massa dan bahkan mengisi konten media massa. Audience sekarang dapat mengontrol kapan, di mana dan bagaimana mereka mengakses dan berhubungan dengan informasi, dalam berbagai jenisnya.

Jurnalisme konvergensi melibatkan kerjasama antara jurnalis media cetak, media siar, dan media Web (online) untuk menghasilkan berita terbaik yang dimungkinkan, dengan menggunakan berbagai sistem penyampaian (delivery). Konvergensi telah terjadi pada dua aspek utama: teknologi dan industri. Pada aspek teknologi: Konten kreatif telah dikonversikan ke dalam bentuk-bentuk digital standar-industri, untuk disampaikan melalui jejaring pita lebar (broadband) atau tanpa-kabel (wireless), untuk ditampilkan di berbagai komputer atau piranti-piranti seperti-komputer, mulai dari telepon seluler sampai PDA (personal digital assistant), hingga ke alat perekam video digital (DVR, digital video recorder) yang terhubung kepesawat televisi.

Pada aspek industri: perusahaan-perusahaan yang melintasi spektrum bisnis, mulai dari perusahaan media ke telekomunikasi sampai teknologi, telah menyatu dan membentuk aliansialiansi strategis, untuk mengembangkan model-model bisnis baru, yang dapat meraih keuntungan dari ekspektasi konsumen yang sedang tumbuh terhadap konten media yang disesuaikan dengan permintaan (on-demand). Sejumlah analis industri memandang, konvergensi media ini menandai memudarnya "media lama" seperti media cetak dan media siar, serta bangkitnya "media baru," yang perkembangannya masih berlangsung dinamis saat ini. 
Media sosial dapat dipahami dengan mengcau pada teori media baru yang dikembangkan oleh Pierre Levy. Dalam teori media baru, interaksi social dibedakan menurut kedekatannya dengan interaksi tatap muka. Pierre Levy memandang World Wide Web (WWW) sebagai sebuah lingkungan informasi yang terbuka, fleksibel dan dinamis, yang memungkinkan manusia mengembangkan orientasi pengetahuan yang baru dan juga terlibat dalam dunia demokratis tentang pembagian mutual dan pemberian kuasa yang lebih interaktif dan berdasarkan pada masyarakat. New Media atau media online didefinisikan sebagai produk dari komunikasi yang termediasi teknologi yang terdapat bersama dengan komputer digital.

Definisi lain media online adalah media yang di dalamnya terdiri dari gabungan berbagai elemen. Itu artinya terdapat konvergensi media di dalamnya, dimana beberapa media dijadikan satu. New Media merupakan media yang menggunakan internet, media online berbasis teknologi, berkarakter fleksibel, berpotensi interaktif dan dapat berfungsi secara privat maupun secara publik. Definisi lain mengemukakan, media baru merupakan digitalisasi yang mana sebuah konsep pemahaman dari perkembangan zaman mengenai teknologi dan sains, dari semua yang bersifat manual menjadi otomatis dan dari semua yang bersifat rumit menjadi ringkas.

\section{METODE PENELITIAN}

Tujuan penelitian ini adalah untuk mengetahui bagaimana model konvergensi yang dilakukan majalah Popular yang merupakan jawaban atas tuntutan eksistensi industri media bahwa media cetak harus mempersiapkan platform digital untuk menghadapi media digital yang terus berkembang. Penelitian ini merupakan penelitian deskriptif kualitatif. Tujuan dari penelitian ini adalah untuk membuat deskripsi, gambaran atau lukisan secara sistematis, faktual dan akurat mengenai fakta-fakta, sifat-sifat serta hubungan antar fenomena yang diselidiki (Cresswell 2009; Sutopo 2006; Nazir 1988). Teknik pengambilan informan melalui teknik purposive sampling (pengambilan informan berdasarkan tujuan). Sedangkan teknik pengumpulan data dilakukan dengan wawancara, dokumentasi dan studi pustaka. Data dalam penelitian ini akan dianalisis secara kualitatif.

\section{HASIL PENELITIAN}

Majalah Popular menjadi ikon majalah pria dewasa di tanah air. Bahkan, pada 24 Mei 2012, Popular mendapatkan penghargaan dari Museum Rekor Indonesia (MURI) sebagai majalah pria dewasa yang bisa bertahan selama 24 tahun di Indonesia sejak tahun 1994. Bagaimanapun juga, Popular memang produk asli Indonesia yang tetap kokoh bersaing menghadapi para pendatang dengan konsep sejenis, misalnya FHM, Maxim, atau bahkan Playboy yang punya nama besar di dunia.

Pendiri Majalah Popular, Heriyadi H. Sobiran, awalnya ingin menerbitkan sebuah majalah yang mengulas olahraga, musik, dan film. Gagasan tersebut lahir karena Indonesia saat itu menjadi tuan rumah Sea Games 1987. Pada 25 Mei 1987, Heriyadi H. Sobiran melalui PT. Nitra Indrya Harsa mengajukan permohonan kepada Menteri Penerangan RI untuk mengeluarkan surat izin penerbitan majalah bulanan. Akhirnya setelah satu semester lebih, surat keputusan nomor 252/SK/MENPEN/SIUPP/D.1/1988 yang ditunggu-tunggu pun turun juga.

Setelah memasang artis Lydia Kandou sebagai model cover edisi percobaan, maka terbitlah edisi perdana Majalah Popular dengan model cover Camelia Malik pada 8 Februari 1988, dengan semboyan "Mereka yang berprestasi". Namun demikian, angka penjualan Popular masih jauh dari 
target yang diharapkan. Untuk itu, Heriyadi H. Sobiran mengambil risiko dengan menyajikan suatu konsep majalah yang belum pernah ada di Indonesia, yaitu konsep foto swimsuit alias pakaian renang. Gagasan tersebut diwujudkan pada edisi ke-38, bulan Maret 1991. Tercatat nama Sophia Latjuba sebagai model swimsuit pertama yang berpose sebagai cover Majalah Popular, disusul Dian Nitami pada bulan berikutnya.

Kontroversi pun berkembang seiring dengan meningkatnya angka penjualan. Dua bulan berikutnya, pihak Popular dipanggil Departemen Penerangan selaku otoritas yang berkuasa atas media saat itu. Bagaimanapun juga, konsep pakaian renang dianggap tabu oleh sebagian besar masyarakat Indonesia. Akhirnya, dicapailah kesepakatan antara kedua pihak. Popular tetap diperbolehkan mengusung konsep foto swimsuit dengan syarat tidak bertentangan dengan lokasi sebagai latar belakangnya. Artinya, model boleh difoto dalam busana swimsuit asalkan berada di pantai, laut, ataupun kolam renang. Begitulah, pada awalnya Majalah Popular memang diterbitkan untuk menyiarkan berita olahraga dan seni, sehingga penampilan swimsuit oleh pihak redaksi dikatakan mewakili cabang olahraga renang.

Popular juga sangat selektif dalam memasang model covernya. Tidak semua wanita bisa berpose menampilkan keindahan tubuhnya di majalah dewasa ini. Ada kriteria-kriteria tertentu yang ditetapkan oleh pihak redaksi. Bahkan, ada seorang artis senior yang semasa mudanya pernah berkata bahwa dia tidak mau difoto memakai swimsuit, kecuali untuk Majalah Popular.

Pada tahun 1999, Popular pernah tersandung kasus pornografi karena menyajikan cover Sophia Latjuba sedemikian rupa, seakan-akan telanjang tanpa busana. Konon foto ini diilhami dari poster Demi Moore yang membuat Popular edisi tersebut laku keras. Pada perkembangan selanjutnya, Popular ternyata tidak hanya memasang cover bertema swimsuit, tetapi juga bikini, bahkan lingerie dan pakaian dalam. Juga ada konsep pakaian seksi kontemporer. Ada juga model cover yang berpakaian gaun, namun tetap memperlihatkan kesan sensual.

Popular sebagai majalah lokal dan sekaligus market leader majalah pria dewasa di Indonesia, juga menyadari tentang ada perubahan di industri media. Pemimpin Redaksi Popular, Faisal Rahim mengatakan industri media saat ini mengalami perubahan seiring dengan perkembangan teknologi informasi. Maka dari itu, Popular mau tidak mau harus berubah menyesuaikan dengan situasi dan kondisi saat ini. Popular harus mangkombinasikan kekuatankekuatan media yang dimiliki baik cetak maupun online. Dengan adanya beberapa platform tersebut, Popular telah mempersiapkan medianya dalam rangka menuju konvergensi sejak dini. Menurutnya, media baru tersebut dipersiapkan sejak dini meskipun era digital di Indonesia khususnya di daerah belum tumbuh seperti di negara-negara maju lainnya.

Platform cetak di Popular tetap dipertahankan dan terus ditingkatkan oplah dan pendapatan iklannya. Sementara online juga harus dipersiapkan sejak dini dan sebisa mungkin mendatangkan penghasilan. Selanjutnya pengelolaannya dikombinasikan oleh masing-masing platform tersebut. Dengan strategi tersebut, jika suatu saat era cetak mulai redup, maka online langsung bisa menggantikan, konvergensi media merupakan pilihan yang harus diambil oleh media baik media cetak maupun televisi.

Media massa harus mampu menyesuaikan dengan perkembangan zaman khususnya di tengah persaingan industri media yang semakin kompetitif. Jika tidak mampu menyesuaikan, maka media tersebut bakal ditinggalkan audiens.

Dari uraian tersebut, maka harus ada kesadaran dari seluruh stakeholders yang ada di majalah Popular bahwa media saat ini telah berubah. Pengelolaan dan cara kerja juga harus berubah. Sebab, konvergensi media telah menuntut cara kerja orang-orang media untuk lebih kreatif 
dan multi tasking, termasuk tim redaksi majalah Popular juga ikut berubah. Kecepatan kerja dalam memproduksi berita menjadi sebuah kebutuhan. Para penghasil berita dituntut harus profesional, dan memiliki loyalitas tinggi. Pekerja media dalam bekerja di era konvergensi bisa untuk beberapa platform. Berita yang ditulis oleh wartawan kini tidak lagi cuma dimuat di satu media, tetapi bisa untuk beberapa media dari beberapa platfom.

Redaktur Pelaksana popular.com mengatakan konvergensi yang dilakukan Popular tahap pertama dilakukan antara lain adalah membuka web situs khusus majalah pria dewasa tersebut, dimana di dalam Web situs tersebut diinformasikan juga fitur dan rubik-rubik isi dari majalah popular edisi cetaknya. Selain itu berlanjut kepada pembuatan account untuk sosial media, salah satunya instagram dengan id @ popularmagazine.id/@miss.popular.id serta account Youtube dengan id "Popular Magazine Indonesia" yang sudah mencapai 700.000 follower dan sudah mendapatkan penghargaan silver buttom dari youtube.

Pada platform youtube ini, Popular membuat semacam web series untuk disajikan kepada para followers-nya dengan tema seperti "inem lumayan seksi", "dosen macan" dan lain sebagainya. Para talent pada webseries tersebut menampilkan para pemenang dari misspopular yang setiap tahunnya diadakan oleh majalah Popular sebagai ajang pencarian bakat wanita-wanita di indonesia yang ingin popular atau terkenal didunia entertainment. Selain itu, di dalam sosial media yang digunakan Popular juga memberikan informasi berupa foto-foto terbaru miss popular pada instagram dan beberapa info kuis dan lain sebagainya.

Pada platform youtube, majalah Popular memberikan info mengenai kegiatan para model pada sesi pemotretan serta kegiatan event-event miss Popular beserta sponsor yang dilakukan di seluruh kota di Indonesia selain tayangan web series yang memiliki tema yang variatif di tiap harinya, membuat para audience media sosial penasaran untuk terus menyaksikan tayangan webseries tersebut, sehingga diharapkan para pengguna sosial media dengan leluasa dapat dengan mudah mengakses dan mengetahui informasi akurat dan terupdate mengenai kegiatan entertaining pada majalah popular.

Dari alur tersebut, konvergensi yang dilakukan di majalah popular masuk pada model konvergensi content. Berita akhirnya disuguhkan dalam bentuk multimedia, yang merupakan kombinasi antara teks, gambar, audio, video, blog, podcasts, atau slide show. Pilihannya terus berkembang. Saat ini, konvergensi isi masih sangat muda atau baru dimulai. Namun, kita dapat mengintip masa depan melalui website yang inovatif. Bayangkan beberapa tahun ke depan medium hybrid baru mengkombinasikan antara audio dan video tv, sifat responsif dan sumber dari website, kemudahan dibawa dan kualitas cetak dari koran. Editor dan reporter akan menjadi content producer yang dilatih untuk memilih cerita mana yang paling efektif, teknik yang paling menghibur dari menu biasa hingga pilihan multimedia.

Komunikasi yang sudah dikonvergensikan menyediakan berbagai macam alat untuk penyampaian berita, dan memungkinkan konsumen untuk memilih tingkat interaktivitasnya, seraya mereka bisa mengarahkan sendiri penyampaian kontennya. Konvergensi media memungkinkan audiens (khalayak) media massa untuk berinteraksi dengan media massa dan bahkan mengisi konten media massa seperti pada rubik tanya jawab dan sebaginya, sedangkan pada web dan sosial media juga mampu menggunakan jalur interaktif dalam berkomunikasi secara langsung dan jarak serta waktu tak lagi menjadi masalah, Audiens sekarang dapat mengontrol kapan, di mana dan bagaimana mereka mengakses dan berhubungan dengan informasi, dalam berbagai jenisnya.

Jurnalisme konvergensi melibatkan kerjasama antara jurnalis media cetak, media siar, dan media Web (online) untuk menghasilkan berita terbaik yang dimungkinkan, dengan menggunakan 
berbagai sistem penyampaian (delivery). Konvergensi telah terjadi pada dua aspek utama: teknologi dan industri. Pada aspek teknologi: Konten kreatif telah dikonversikan ke dalam bentuk-bentuk digital standar-industri, untuk disampaikan melalui jejaring pita lebar (broadband) atau tanpa-kabel (wireless), untuk ditampilkan di berbagai komputer atau piranti-piranti seperti-komputer, mulai dari telepon seluler sampai smartphone yang sekarang makin canggih.

Pada aspek industri: Perusahaan-perusahaan yang melintasi spektrum bisnis, mulai dari perusahaan media ke telekomunikasi sampai teknologi, telah menyatu dan membentuk aliansialiansi strategis, untuk mengembangkan model-model bisnis baru, yang dapat meraih keuntungan dari ekspektasi konsumen yang sedang tumbuh terhadap konten media yang disesuaikan dengan permintaan (on-demand). Sejumlah analis industri memandang, konvergensi media ini menandai memudarnya "media lama" seperti media cetak dan media siar, serta bangkitnya "media baru," yang perkembangannya masih berlangsung dinamis saat ini.

Adanya konvergensi media ini mengharuskan untuk industri-industri media memiliki lebih dari satu media untuk dapat menjalankan multiplatform media. Multiplatform disini memberikan industri media sebuah keuntungan dikarenakan satu media dengan media lainnya dapat saling melengkapi. Seperti halnya media cetak, Popular yang bergabung dengan internet membentuk sebuah berita di dalam majalah cetak dengan digabungkannya sebuah siaran video di dalam media online. Beberapa bentuk perkembangan yang diberikan oleh majalah Popular untuk para pembacanya tersebut merupakan salah satu bentuk penyampaian informasi dengan tampilan multimedia dan multiplatform media.

Konvergensi media tersebut juga mengubah pola-pola hubungan produksi dan konsumsi yang dalam penggunaanya akan berdampak serius pada ekonomi, politik, pendidikan, dan budaya dalam masyarakat. Konvergensi media memadukan ciri-ciri komunikasi massa dengan antarpribadi yang dilakukan dalam satu media sekaligus. Arus informasi yang berlangsung menjadi makin personal, karena tiap orang mempunyai kebebasan untuk memilih informasi yang mereka butuhkan.

Konvergensi media saat ini dapat menggeser banyak media khususnya media cetak karena media online seperti internet mengalami peningkatan dari tahun ke tahun yaitu dari tahun 2004 hingga tahun 2012. Namun, media cetak memiliki fungsi koreksi terhadap berita yang menyimpang karena alur media cetak saat akan diterbitkan memiliki alur yang terstruktur dan dapat dipertanggungjawabkan. Media cetak juga bisa memberikan wahana hiburan seperti gambar dan animasi sehingga para pembaca tidak bosan saat membaca informasi. Walaupun media online mudah diakses, cepat, dan biayanya lebih murah akan tetapi terkadang berita yang disampaikan seringkali menyimpang dan tidak dapat dipertangungjawabkan karena beberapa penulis dari media online adalah masyarakat biasa dan non professional sehingga muncul fenomena citizen journalism.

Dengan banyaknya citizen journalism, masyarakat jadi kesulitan memilah mana berita yang dapat dipertanggungjawabkan dan mana yang tidak. Bukan berarti wartawan tidak diperlukan, justru dengan adanya perkembangan konvergensi media, wartawan semakin mendapatkan informasi yang cepat dan berbobot. Konvergensi yang ada tidak hanya menggeser teknologi melainkan juga paradigma industri, budaya, dan sosial yang mendorong masyarakat untuk mencari informasi baru. Gerakan konvergensi tersebut muncul akibat adanya era digital atau internet. Konvergensi memiliki 3 C yaitu computing (memasukkan data melalui komputer), communication (komunikasi), dan content (isi materi/konten).

\section{KESIMPULAN}


Konvergensi media yang dilakukan majalah Popular merupakan jawaban atas tuntutan eksistensi industri media bahwa media cetak harus mempersiapkan platform digital untuk menghadapi media digital yang terus tumbuh dan berkembang di era new media ini yang mereka lakukan dalam bentuk konvergensi content pada teks, gambar, audio, video, blog, podcasts, atau slide show. Editor dan reporter menjadi content producer yang dilatih untuk memilih cerita mana yang paling efektif, teknik yang paling menghibur dari menu biasa hingga pilihan multimedia.

Sementara itu, adanya beban kerja untuk beberapa platform belum diimbangi dengan pemberian penghargaan khusus berupa materi kepada para awak redaksi yang terlibat dalam mendukung konvergensi media, sedangkan teknologi memiliki peran yang sangat penting dalam mendukung konvergensi media. Konvergensi media adalah suatu keharusan agar mampu bersaing di tengah agresifnya era media digital saat ini. Konsep online first harus diingatkan terus menerus kearah media hybrid dan untuk itu tenaga kreatif perlu sensitif membaca arah minat audience sehingga tidak kehilangan pangsa pasarnya.

\section{Daftar Pustaka}

August, E Grant dan JS. Wilkinson. (2009). Understanding Media Convergence: The State of the Field. New York: Oxford University Press.

Cresswell, J.W. (2009). Research Design: Pendekatan Kualitatif, Kuantitatif and Mixed. Edisi Ketiga. Yogyakarta: Pustaka Pelajar.

Flew, Terry. (2002). New Media: An Introduction. Melbourne: Oxford University Press.

Jenkins, Henry. 2006. Convergence Culture, Where Old and New Media Collide. New York: New York University Press.

Katadata.co.id, upload 7 Desember 2017.

Nainggolan, Bestian. (2017). Market Typology, Concentration, and Competition of National Media

Conglomerate in Indonesia. Jurnal Komunikasi Ikatan Sarjana Komunikasi Indonesia. Vol 2(1): 27-32

Nazir, Muhammad. (1988). Metode Penelitian. Jakarta: Ghalia.

Ritonga, Rajab, Endah Murwani, dan Syafruddin Ritonga. (2017). Gender Awareness of Maria

Hartiningsih as Daily Kompas Reporter. Jurnal Komunikasi Ikatan Sarjana Komunikasi Indonesia, Vol 2(2): 82-91.

Ritonga, Rajab. (2007). Reposisi Ekonomi Politik Kantor Berita di Era Konvergensi Media: Studi

Komodifikasi Informasi di Newsroom Kantor Berita Nasional dan Kantor Berita Internasional. Disertasi. Universitas Indonesia.

Fidler, Roger. (2003). Mediamorfosis. Yogyakarta: Bentang.

Sutopo, HB. 2006. Metodologi Penelitian Kualitatif Dasar Teori dan Terapannya Dalam Penelitian, Surakarta: Universitas Sebelas Maret Press. 